\title{
Mencari Relevansi Teori dalam Menganalisis Sikap MPR 1998-2000 terhadap Gagasan Negara Hukum yang Demokratis
}

\author{
Margarito Kamis
}

\begin{abstract}
A sociological approach is the relevant and appropriate one to clarify the current phenomena in line with administrative law. Its significance can be traced from three views; firstly, interaction and interrelationship among the phenomena: law, economy, politic and culture have been considered more important toward aspects of the current state affairs issue. Secondly, hope, perception, and value are continuously developed and rapidly changeable. Theoretically and practically, the change has an influence to the state affairs system. Thirdly, historically the state affairs form of a country provides as well as constitutes a reflection of dynamic and interaction among politic, economy, law, and cultural dimensions at that time. Ethical quality and state affair philosophy of a country should be investigated and put into their context.
\end{abstract}

\section{Pendahuluan}

Negara hukum, demokrasi, otokrasi atau apapun namanya merupakan penanda atas suatu negara. Menandai suatu negara sebagai negara hukum, acapkali membingungkan. Demikian juga menjelaskannya dalam konstitusi, jika negara tersebut memiliki konstitusipun, tidak serta membuat negara tersebut benar-benar merupakan sebuah negara hukum. Konstitusi tertulis atau tidak tertulis, betapapun lengkapnya, tidak dapat berbicara sendiri. Di tangan aparatur negaralah ia dilaksanakan. Pasang surut pelaksanaan negara hukum di Indonesia harus dipahami dalam konteks tersebut. Lev, ${ }^{1}$

'Daniel S. Lev. 1978. "Judicial Authority and the Struggle for an Indonesian Rechstaat." Law and Society Review. hlm.13. 
mengakui gerakan memperjuangkan pelaksanaan negara hukum, tidak timbul dari ruang kosong. Gerakan tersebut berlangsung dalam kelompok-kelompok yang tidak beruntung karena adanya pola pengaturan politik, ekonomi dan sosial yang diskriminatif.

Pasang surut pemerintahan di Indonesia, menunjukkan betapa tidak mudah, bahkan tidak berartinya konseptualisasi negara hukum Indonesia yang dipatrikan dalam penjelasan UUD 1945. Penjelasan UUD 1945, secara tegas mematrikan Indonesia sebagai negara hukum. Demikian juga pemerintahan dijalankan berdasarkan hukum. Dalam pengertian yang umum kata-kata "berdasarkan hukum" dimengerti sebagai tindakan pemerintahan harus dapat dipertanggung jawabkan. Tindakan tersebut harus dapat dinalar berdasarkan prinsip-prinsip hukum. Demikian juga harus dapat dikoreksi secara hukum, tentu bila ia tidak memenuhi standarstandar hukum. Secara singkat, hukum merupakan suatu batasan normatif atas kekuasaan. Peters dan Koesriani Siswosebroto ${ }^{2}$ melihat kekuasaan berdasarkan hukum bertujuan untuk mendepersonalisasi kekuasaan. Maksudnya adalah untuk menundukkan pelaksananya kepada aturanaturan hukum. Sekaligus melindungi warga negara dari tindakan sewenang-wenang penguasa. Karena itu, seringkali hukum dilihat sebagai antitesa terhadap kekuasaan. Menjalankan kekuasaan berdasarkan hukum, secara teoritik sama artinya dengan membatasi kekuasaan tersebut. Tetapi postulasi tersebut tidak terlampau benar dalam tataran praksis. Secara praksis terdapat relasirelasi yang dilematis. Relasi antara hukum dengan kekuasaan pada dirinya mengandung potensi dilematis. Letak dilematisnya adalah kekuasaan membutuhkan keleluasaan bergerak, terutama pada konteks adminsitrasi. Di sisi lain, gerak kekuasaan harus berada di bawah kontrol dan berdasarkan hukum. ${ }^{3}$

Sejarah Indonesia menunjukkan pergeseran kekuasaan telah terjadi pada periode awal kemerdekaan. Setidak-tidaknya ketika terjadi pergeseran dari kabinet presidensial, walaupun tidak mumi ke sistem yang bersifat pariementer. Pergeseran tersebut diawali dengan dikeluarkannya Maklumat Wakil Presiden No. X Tahun 1945.4 Bagaimana dengan pergeseran dari negara hukum menjadi negara otoriter. Pergeseran ini terjadi ketika Soekamo, Presiden Indonesia pertama tersebut mendekritkan keputusannya untuk kembali ke UUD 1945 dan memperkenalkan demokrasi terpimpin. Tindakan ini dinilai oleh Jhones ${ }^{5}$ sebagai suatu tindakan diktatorial. Babak kedua penyelewengan negara hukum, kembali terjadi. Kali ini dilakukan oleh Soeharto, walaupun pada awal

${ }^{2}$ A.A.G. Peters dan Koesriani Siswosoebroto. 1990. "Hukum dan Perkembangan Sosial." Buku Teks Sosiologi Hukum Buku III. Jakarta: Sinar Harapan. HIm. 53.

3Yusril Ihza Mahendra. 1996. Dinamika Tatanegara Indonensia (Kompilasi Aktual Masalah Konstitusi, Dewan Perwakilan dan Sistem Kepartaian). Jakarta: Gema Insani Press. HIm 45.

4Ismail Suny. 1986. Pergeseran Kekuasaan Eksekutif. Jakarta: Aksara Baru. HIm. 28.

${ }^{5}$ Howard Palfrey Jhones. 1980. Indonesia: the Posible Dream. Singapore/Jakarta: Gunung Agung. HIIm. 240.241. 
kekuasaannya, dimaksudkan sebagai sebuah koreksi total atas penyimpangan yang dilakukan Soekarno. Kekuasaan Soeharto, secara simbolis dan politis dipatrikan sebagai kekuasaan yang akan melaksanakan konstitusi secara murni dan konsekuen. ${ }^{6}$ Hasilnya adalah suatu penyelewengan negara hukum secara konsekuen.

\section{Dimensi Empiris Negara Hukum}

Menelusuri kebangkitan dan perjalanan gagasan negara hukum, demikian juga implementasinya, ibarat suatu garis bergelombang. Acapkali mengalami patahan, titik balik yang tak terhindarkan. Tetapi seperti biasanya, setiap kali terjadi stagnasi, selalu merupakan rangsangan dan titik balik bagi sebagian orang untuk melakukan perlawanan. Cita-cita suatu komunitas, untuk tidak menyebut semuanya, karena kesadarannya, dalam mana pemerintahan berdasarkan hukum, pemerintahan perwakilan dan terjamin beberapa hak dasar selalu menjadi pemasok energi untuk melakukan perlawanan. Kesadaran lain yang turut menjadi energi perlawanan adalah demokrasi, betapapun ambigunya konsep tersebut. Demokrasi menjanjikan kesempatan yang sama terhadap semua orang untuk mengaktualisasikan dirinya.?

Inggris, menjadi penyumbang terbaik gagasan negara hukum. Walaupun pada awalnya hanya dibatasi pada isu hak asasi manusia. Magna Charta 1215, kendati sering disalah-persepsikan sebagai piagam hak asasi, tetapi tidak dapat dingkari bahwa, tanpa piagam ini terlampau sulit untuk menjelasskan negara hukum Inggris. Dalam uraiannya, Davidson $^{8}$ menjelaskannya Magna . Charta 1215 lebih merupakan kompromi antara kaum bangsawan dengan Raja Jhon tentang pembagian kekuasaan antara raja dengan kaum bangsawan. Kata-kata hak asasi tersebut baru memperoleh makna yang luas, setelah dibuatnya Bill of Rights (1689). Pada Bill inilah untuk pertama kalinya muncul ketentuan-ketentuan untuk perlindungan hakhak atau kebebasan individu. Sebagaimana diperikan dalam judulnya An Act Declaring the Rights and Liberties of the Subject and Setting the Succession of the Crown merupakan hasil perjuangan parlemen melawan pemerintahan raja-raja Gangsa Stuart yang sewenangwenang pada abad ke 17. Piagam ini disahkan setelah raja James II dipaksa turun tahta dan William III dan Mary II naik tahta, menyusul revolusi gemilang The Glorius Revolutions, pada tahun 1688. Kekuasaan diperlemah oleh parlemen.

Magna Charta 1215, lebih-lebih Bill of Rights 1689 menunjukan suatu hal yang sangat berarti bagi perjuangan menumbangkan kekuasaan despotik. Memaksa membagikan kekuasaannya dengan pihak lain, kaum bangsawan misalnya, menandai suatu tesis

${ }^{8}$ Abdulharis Nasution. 1966. Ketetapan-Ketetapan MPRS 1966. Jakarta: Tanpa Penerbit. HIm. 22.

'David Apter. 1996. Pengantar Analisa Politik. Jakarta: LP3ES. HIm. 168.

"Scott Davidson. "Human Rights." Terjemahan A. Hadyana Pujaatmaka. 1994. Hak Asasi Manusia. Jakarta: Pustaka Utama Grafiti. HIm. 2-3. 
bahwa kekuasaan dapat dipaksa untuk tunduk pada kemauan orang banyak. Bukan itu saja kekuasaan pun dapat dibubarkan bila dilawan, jika kekuasaan tersebut sewenang-wenang. Bagaimana dengan Amerika Serikat? Sebagai sebuah koloni Inggris, mereka dipaksa untuk membayar pajak yang sangat memberatkan. Di samping itu Revolusi Inggris Glorius Revolution turut disertakan sebagai pemasok energi perlawanan. Seperti terlihat dalam Declaration of Independence-nya (1776), yang disusun oleh Thomas Jefferson, katakata kesamaan derajat sebagai manusia, hak terpatrikan dengan sendirinya sebagai manusia terlihat amat jelas. Berikut ini cuplikan sebagian dari kata-kata tersebut "Kami menganggap kebenaran-kebenaran berikut sudah jelas dengan sendirinya: bahwa menusia diciptakan sama, bahwa penciptanya telah menganugerahi mereka hak-hak tertentu yang tidak dapat dicabut. Bahwa sebagian dari hak tersebut adalah hak untuk hidup, dan mengejar kebahagiaan. Bahwa untuk mengejar kebahagiaan ini orang mendirikan pemerintahan, yang memperoleh kekuasaannya yang benar berdasarkan persetujuan yang diperintahnya. Kapan saja suatu pemerintahan merusak tujuan-tujuan ini, rakyat berhak mengubah atau menyingkirkannya. ${ }^{9}$

Berbeda dengan Amerika, Perancis, mungkin memiliki sedikit kesamaan dengan Inggris. Jika Amerika berusaha menjadi suatu bangsa yang berdaulat dan merdeka, maka Perancis justru berusaha menghancurkan pemerintahan yang absolut. Soalnya adalah bagaimana menciptakan suatu legitimasi. Apakah kekuasaan absolut tersebut dengan sendirinya menjadi legitimasi gerakan mereka? Jika kekuasaan yang absolut dijadikan legitimasi gerakan, pertanyaannya adalah dari mana orang memperoleh hak untuk menghancurkan kekuasaan absolut tersebut. Solusi teoritis yang dikemukakan untuk memecahkan problematik itu adalah rakyatlah yang berkuasa. Isu ini menjadi tesis sentral gerakan perlawanan Perancis. Dali] sentral konsep ini: kedaulatan suatu negara di tangan rakyat. Karenanya, pemerintahan haruslah di tangan rakyat. Setiap pemerintah yang tidak tanggap terhadap tuntutan warga negaranya dapat diubah dengan pernyataan kehendak rakyat. ${ }^{10}$

Memindahkan kedaulatan, dari raja ke rakyat, atau dari negara ke rakyat, dan memasung kekuasaan dengan hukum, belum benar-benar menjamin terselenggaranya suatu negara hukum. Pemerintah, dapat disinggkirkan setiap saat, dengan alasanalasan hukum. Tetapi, dapat juga terjadi sebaliknya. Negara, tentu setelah memberikan kerangka normatif terhadap kebijakannya, legitimasi formal dapat memaksakan kehendaknya. Dalam banyak kenyataan, tidak seluruh rakyat memperdulikan pengelolaan negara. Banyak penyimpangan, tidak serta membuat rakyat mengikhtiarkannya dengan suatu tindakan yang produktif konstitusional. Secara empiris pula, tidak mudah membuat rakyat untuk secara terus menerus

9Steven B. Presser \& Jamill S. Jainaldin. 1980. Law and American History. New York: Wets Publishing Co. HIm. 114-115.

${ }^{10}$ Scott Davidson. Op Cit. HIm. 5-6. 
mengikhtiarkan kekuasaan dengan menggunakan haknya. Postur negara hukum Jerman di bawah Hitler merupakan suatu preseden menarik. Di bawah idiologi Nazi, hakhak dasar manusia disandera. Doktrin Hitler, tidak saja menguasai alam pikiran politik, tetapi merambah hingga proses peradilan. Hukum, yang digunakan tidak lagi netral. Hukum, berpihak bahkan dianugrahkan untuk mengkonsolidasikan doktrin Hitler. Nasionalisme Jerman, dimanipulasikan sedemikian rupa hingga memunculkan suatu pemerintahan fasis. Ciri utama adalah penggunaan teror, pengagungan seseorang, permusuhan terhadap keaneka-ragaman, konflik internal dan tidak adanya kekangan hukum bagi penguasa. " Ciri ini juga ditemukan pada kekuasaan Stalin di Uni Soviet. ${ }^{12}$ Jika di Amerika Serikat, yang ditekankan dalam rule of Law adalah Freedom, maka di Uni Soviet ditekankan pada Responsibility. ${ }^{13}$

Kasus negara hukum Indonesia menampilkan sebuah keunikan. Di bawah UUD 1945 yang dinyatakan kembali diberlakukan oleh Soekarno justru negara hukum diselewengkan. Penyelewengan itu tejadi ketika Soekamo, dengan kekuasaannya membubarkan dan membentuk sendiri MPRS.
Pembentukan yang dilegitimasi dengan Penpres No. 2 Tahun 1959. Demikian juga pembentukan DPR-GR. Soekarno kembali menggunakan Penpres, senjata pamungkasnya, No. 4 Tahun 1960 membubarkan DPR yang terbentuk berdasarkan UU No. 7 Tahun $1953^{14}$ Soekarno kemudian digantikan oleh Soeharto. Soeharto, memberikan harapan kepada banyak pihak dengan mematrikan kekuasaannya sebagai kekuasaan yang hendak melaksanakan UUD 1945 secara murni. Tetapi, ternyata terlampau naif untuk mengatakan bahwa Rezim baru benar-benar melaksanakan negara hukum. Hukum justru digunakan secara konsisten untuk mengkonsolidasi kekuasaannya. Negara, di bawah Soeharto tidak lebih sebagai sebuah Otoriter Birokratik Rente. ${ }^{15}$ Partai Politik dibatasi perannya. Hak politik pegawai negeripun digerogoti. Mereka hanya menyalurkan aspirasi politik, kalau ada dan diperkenankan kepada Golkar, pilar utama Kekuasaan Soeharto. Militer, diperluas peran sosial politiknya. Pemilihan umum yang dilaksanakan secara berkala oleh Orde Baru tidak mewakili apalagi mempromosikan kedaulatan rakyat. ${ }^{16}$ Sumberdaya ekonomi dikelola secara sentralistik dengan pola

"Charles F. Andrian. "Political Life and Social Change." Terjemahan Luqman Hakim. 1992. Kehidupan Politik dan Perubahan Sosial. Jakarta: Tiara Wacana. HIm. 301-302.

'il lbid.

${ }^{13}$ Oemar Seno Adji. 1980. Peradilan Bebas Negara Hukum. Jakarta: Erlangga. Hlm. 19.

"Beny K. Harman. 1997. Konvigurasi Politik dan Kekuasaan Kehakiman Di Indonesia. Jakarta: ELSAM. HIIm.123-124.

${ }^{15}$ Arief Budiman. 1991. Negara dan Pembangunan: Studi Tentang Indonesia dan Korea Selatan. Jakarta: Padi dan Kapas. HIm. 53.

${ }^{18}$ Dewi FortunaAnwar. "Format Politik Orde Baru dan Agenda Pengembangan Demokrasi Politik". Dalam Syarofin Arba; Ed. 1998. Demitologisasi Politik Indonesia, Mengusung Elitisme Dalam Orde Baru. Jakarta: CIDES. HIm. 3. 
governance as privat enterprise. Distribusi sumber daya ekonomi berjalan dengan pola distributional coalition $s^{17}$ Ikhtiar Soeharto untuk melunakkan penyelewengan negara hukum seolah berlomba dengan waktu. la harus turun dari kekuasaan setelah dipaksa rakyat yang ditekannya selama bertahun-tahun, menyusul krisis ekonomi yang sangat dahsyat pada tahun 1997.

\section{Melacak Relevansi Teori}

Filsafat hukum alam ternyata telah merangsang pertumbuhan pemikiran tentang hak asasi manusia. Demikian juga tentang negara dan hukum. Penegasan tentang kesamaan derajat bagi semua orang merupakan salah satu sumbangannya. Konstruksinya relatif lebih mudah. Tetapi berbeda ketika negara dan hukum dikonstruksikan. Menampilkan penggunaannya alam dalam mengkonstruksikan hak asasi manusia, tidak berarti mengabaikan pertentangan di dalamnya. Tahap-tahap perkembangan hukum alam menampilkan perbedaan-perbedaan itu. Perbudakan, bagaimanapun pernah muncul sebagai suatu pranata yang mendapat legitimasi hukum alam. Hingga beberapa waktu kemudian, sekitar abad pertengahan baru lembaga, bukan saja perbudakan, melainkan misalnya supremasi hukum tuhan, dengan akal yang paling agung secara gradual dideligitimasi. ${ }^{18}$

Friedman ${ }^{19}$ menjelaskan bahwa Grotius dan golongan rasionalis memiliki tujuan yang sama dengan para teoritikus abad pertengahan. Kalangan ini beranggapan bahwa merekalah yang membentuk tatanan objektif. Revolusi Inggris tahun 1688, Perancis 1789, dan Deklarasi Kemerdekaan Amerika Serikat, hukum alam digunakan oleh individu yang sedang mencapai puncaknya untuk tujuan yang berbeda. Pada abad pertengahan pula banyak penulis mengemukakan pandangannya tentang sumber hukum. Menurut Friedman, ${ }^{20}$ Salisbury, sebagaimana dikenali dari buku yang dipersiapkannya; "Politicraticus" mengakui negara, yang sebelumnya ditolak eksistensinya, justru menurut Salibury merupakan suatu institusi yang berguna bagi masyarakat. Di bidang hukum, Friedman melihat, walaupun untuk sebagian masih berhubungan dengan filsafat hukum alam, selebihnya mulai memperlihatkan skeptisisme terhadapnya. Sebab pada saat yang sama, bermula dari prinsip hukum alam pula teori-teori hukum mulai mempersiapkan prinsip National Sovereignty, untuk abad-abad berikutnya. Pemikir-pemikir hukum pada abad tersebut, mulai membangun pemikirannya berdasarkan kontrak sosial, tegas maupun samar-samar.

\footnotetext{
"Sritua Arief. 1997. Pembangunanisme dan Ekonomi Indonesia Pemberdayaan Rakyat dalam Arus Globalisasi. Jakarta: Zaman. HIm. 53.

18W. Friedman. "Legal Theory". Terjemahan Muhamad Arifin. 1990. Teori dan Filsafat Hukum, telaah Kritis atas Teori-teori Hukum (susunan I). Jakarta: Rajawali. Hlm. 57-58.

${ }^{19} \mathrm{lbid}$. HIm. 73-74.

${ }^{20 / b i d . ~ H I m . ~} 54$.
} 
Pendapat sebelumnya yang menyatakan bahwa kekuasaan politik bersumber dari Tuhan ditolak. Sebabnya adalah dalil itu melahirkan penguasa yang sewenangwenang dan absolutis.

Delegitimasi kekuasaan absolut di satu pihak dan justifikasi atas kekuasaan yang didasarkan pada kehendak rakyat berdasarkan kontrak, didasarkan pada sebagian prinsip hukum alam. Secara ringkas mendeligitimasi dan menjustifikasi kekuasaan rakyat didasarkan pada prinsip-prinsip hukum alam. Inilah problemanya, setidak-tidaknya terlihat relasi dilematiknya. Seiring dengan keruntuhan hukum alam, muncullah aliran hukum positif. Cukup banyak pemikir dalam aliran ini. Kendati demikian tidak semua pemikiran tersebut diuraikan dalam tulisan ini.

Jika hukum alam memiliki fungsi ganda, karena di atas landasan hukum alam, kekuasaan absolut ditolak. Demikian juga di atas landasan hukum alam, pemikiran tentang negara hukum yang demokratis dibangun. Bagaimana dengan positivisme? Positivisme pada dasarnya merupakan reaksi terhadap hukum alam. Tetapi apakah dimensi-dimensi hukum alam benar-benar dikesampingkan? Secara faktual, tidak demikian. Terdapat banyak dimensi hukum alam yang diintroduksi ke dalam paham positivisme. Paham kesamaan kedudukan misalnya merupakan satu dari beberapa dimensi yang diintroduksi ke dalam positivisme.

Dalam menerangkan negara dan hukum, aliran ini sebagaimana diyakini oleh Schimid ${ }^{21}$ dalam abad ke 19, praktis tenggelam, digantikan oleh aliran Naturalis dan Organisme. Dalam hal itu arti hukum positif makin bertambah dalam negara. Buktinya adalah kemenangan kaum revolusioner pada tahun 1789. Kitab Undang-Undang yang berpedoman pada hasil karya Napoleon, dibanyak negara semakin kuat kedudukannya. Di dalamnya dinyatakan bahwa seorang hakim boleh memutuskan perkara di antara pihak-pihak yang bersengketa. Mereka wajib menyerahkan sengketanya pada keputusan pengadilan.

Hukum tampil sebagai simbol kekuasaan yang mengagumkan. Tetapi dengan menampilkan dan menempatkan hukum demikian tinggi kedudukannya, rupanya menimbulkan masalah tersendiri. Hukum, tidak dapat dipakai sebagai satu-satunya parameter untuk menjelaskan negara hukum. Dinamika penyelenggaraan, temyata melahirkan distorsi yang dapat menggerogoti hakikat hukum. Negara hukum Inggris, misalnya tidak dapat dijelaskan semata-mata berdasarkan hukum. Kuatnya kedudukan dan peranan parlemen, di samping kepercayaan yang luar bisa terhadap hukum, merupakan salah satu faktor penentu eksistensi negara hukum Inggris. Bukan saja rakyat tunduk pada hukum, melainkan penguasa juga ikut menghormati dan tunduk pada hukum. Karena hukum yang dibuat memenuhi standar keadilan. Apalagi hakim-hakimnya sangat berwibawa dan ahli di bidangnya: ${ }^{22}$

${ }^{21} \mathrm{~J} . J$. Von Schimid. "Het Denken Over Staat En Rect In de Negentiende Eeuw". Terjemahan Buntarman. Negara dan Hukum. 1985. Jakarta: Erlangga. Him. 161.

2Sunaryati Hartono. 1969. Apakah The Rule of Law Itu?. Bandung: Alumni. Hlm. 15. 
Masalahnya adalah bagaimana menjelaskan hal itu, misalnya di atas landasan teoritik yang dikemukakan Austin. Politik, ekonomi, moral dan budaya tidak mendapat tempat dalam hukum. Jika demikian halnya bagaimana menjelaskan unsur keadilan yang hendak dituju oleh hukum? Ide Austin tentang Sovereignty sebagaimana digambarkan oleh Chand ${ }^{23}$ sangat membahayakan prinsip negara hukum. Ketaatan orang pada hukum merupakan sesuatu yang mutlak, bukan karena hukum itu adil, melainkan dibuat oleh kekuasaan. Idiologinya adalah mempertahankan atau mempromosikan ketertiban atau stabilitas. Sedikit berbeda dengan Austin, Hart teoritisi positivis inipun sedikit memberikan ruang bagi diterimanya bahan-bahan non hukum. Tetapi, bukan tanpa masalah. Masalahnya introduksi dimensi non hukum tersebut baru terjadi manakala suatu sengketa dibawa kepengadilan. Manakala hakim tidak menemukan pengaturan yang cukup barulah dilakukan pencarian terhadap hal-hal non hukum. Hart menyebut bahanbahan non hukum dengan "legaly texture atau open texture. ${ }^{n 24}$ Pembagian aturan hukum yang dilakukan Hart ke dalam primary law dan secondary law, sesuai substansinya, khususnya primary law memungkinkan diterimanya apa yang disebut legaly texture atau open texture tersebut. Tetapi tetap tidak menghilangkan paradigma positivis yang menekankan bahwa dibuat oleh penguasa. Otoritas atau otonomi relatif hukum, bukan ditentukan oleh kesesuaiannya dengan gagasan keadilan masyarakat, melainkan ditentukan oleh otoritas pembuatnya. ${ }^{25}$

Kendati terdapat kelemahan ide-ide positivisme dalam menjelaskan dimensidimensi elementer negara hukum, ia memiliki sumbangan pada dimensi tertentu. Ide positivisme tentang hierarki aturan hukum merupakan salah satu elemen kunci dalam negara hukum. Walaupun diakui, kesesuaian ide tersebut bukan semata-mata karena negara hukum. Kesesuaian ide tersebut lebih merupakan konsekuensi dari terbentuknya sistem hukum dalam suatu negara hukum. ${ }^{26}$

Mengandalkan otoritas hukum sematamata pada otoritas pembuatnya (legislator) secara empirik menimbulkan masalah. Masalahnya adalah netralitas hukum dapat dimanipulasi oleh kekuasaan. Apalagi jika kekuasaan diberikan kewenangan untuk membuat hukum. Berkurangnya nilai negara hukum Amerika disebabkan oleh Presiden dapat memveto suatu undang-undang yang dibuat atau telah disetujui oleh Kongres. ${ }^{27}$ Tidak dapat dilupakan bahwa terminologi negara hukum Formal merupakan gambaran

\footnotetext{
${ }^{23}$ Hary Chand. 1994. Modern Jurisprudence. Kuala lumpur: Turbo. HIm. 80-81.

${ }^{24}$ Richard A. Posner. 1996. Law and Legal Theory in England and America. Oxford: Clarendom Press. HIm 14. Him. 29

${ }^{25}$ Joseph Raz. 1983. The Authority of Law, Essays on Law and Morality. Oxford:Clarendom Press.

${ }^{26}$ Lawrence M. Friedman. 1975. The Legal System, A Social Sciences Perspective. New York: Russel Sage Fundation. HIm. 40.

${ }^{27}$ David Apter. Op. Cit. HIm. 158.
} 
penggunaan hukum yang ketat oleh kekuasaan. Sebuah negara otoriter yang mengandalkan hukumpun dapat disebut negara hukum; negara hukum formal. Esksistensi negara hukum formal diukur berdasarkan eksistensi kelembagaan atau organ-organ negara. ${ }^{28}$

Negara hukum demokratis atau materil ${ }^{29}$ merupakan konsep yang dinamis. Dinamikanya terletak pada elemen-elemen dasar yang dikandungnya. Jenis dan ragam hak asasi manusia, demikian juga kualitas demokrasi serta tafsir atas kedaulatan rakyat misalnya merupakan konsep-konsep yang dinamis. Sehingga dalam perkembangannya dibutuhkan penyesuaian-penyesuaian. Karakter hukum yang dituntut adalah hukum harus bersifat responsif. ${ }^{30}$ Peringatan Lev ${ }^{31}$ tentang upaya mewujudkan negara hukum, tidak terlepas dari bekerjanya faktor-faktor non hukum: politik, sosial dan budaya suatu masyarakat menjadi sangat penting untuk dipertimbangkan: Khususnya dalam menimbang penggunaan teori dan atau paradigma dalam menjelaskan negara hukum yang demokratis.

\section{Signifikansi Teoritik}

Dinamika negara hukum, rupanya merupaka. faktor penentu, jika bukan karena para positivis sengaja mengesampingkan kegagalan positivisme menjelaskan negara hukum yang demokratis. Tidakkah harus dipertanyakan para sosiolog bahwa apakah rakyat dapat membuat hukum sendiri. Demikian juga bisakah hukum yang dibuat sendiri tersebut dapat dipaksakan kepada siapa saja dalam negara? Judul tulisan ini sesungguhnya mengasumsikan penggunanan paradigma sosiologis. Sebagaimana dibayangkan oleh para sosiolog (Sociological Jurisprudence) hukum merupakan refleksi atas pertarungan, relasi antar kepentingan dan kekuatan; politik maupun ekonomi bahkan budaya dalam masyarakat.

Pound, demikian juga Parson dan Philip Zelsnick, untuk menyebut beberapa nama di antara pakar Sociological Jurisprudence, sebagaimana dijelaskan Lyod ${ }^{32}$ memandang hukum sebagai hasil dari relasi-relasi empiris dalam kehidupan sosial masyarakat. Parson misalnya menganalisis relasi antara legal system dengan political System. Memang analisis seperti ini menjadi mutlak karena Parson menggunakan pendekatan Fungsional. Soalnya sebetulnya tidak terletak pada pendekatan tersebut. Tetapi bagaimana hukum sebagai suatu realitas dalam masyarakat dibayangkan oleh Parson. Di lain sisi, Pound sebagaimana dijelaskan oleh Lloyd's menyatakan bahwa jika fungsi hukum dikembangkan sebagai alat kontrol masyarakat

23W. Frideman. Op.Cit. Him. 489.

${ }^{29}$ Ibid.

${ }^{30}$ Mulyana W. Kusuma. 1988. Hukum, Politik dan Perubahan Sosial. Jakarta: YLBHI. HIm. 21.

"Daniel S. Lev. 1991. Hukum dan Perubahan Politik Dilndonesia, Kesinambungan dan Perubahan. Jakarta: LP3ES. HIm. 39.

${ }^{32}$ Loyd's and M.D.A Freeman. 1985. Introduction to Jurisprudence. London: Steven \& Son. HIm. 575-577. 
(Amerika) sesuai perkembangannya, maka tidak bisa lain kecuali harus diselaraskan dengan kebutuhan sosial masyarakat.

Bagaimana menjelaskan sikap MPR dan gagasan negara hukum dalam konteks sosiologi. MPR merupakan sebuah lembaga yang memiliki otoritas "legal power maupun no rival authority. Berdasarkan kekuasaan dan kewenangan yang disandangnya, maka lembaga ini dapat mereformulasi gagasan negara hukum dan menuangkannya ke dalam: UUD atau melalui ketetapannya. Di sisi lain, keanggotaan MPR berasal dari selain partai politik, juga utusan golongan dan daerah. Mereka memiliki kepentingan politik yang berbeda antara satu dengan lainnya. Di sisi lain masyarakat pun memiliki agenda tersendiri, setidaknya menghendaki agar direformulasi atau menegaskan ukuran-ukuran negara hukum.

Kenyataan tersebut di atas menandakan bahwa terdapat demikian banyak kepentingan yang harus dikompromikan. Bagi anggota MPR sendiri kepentingan mereka akan menentukan sikap mereka terhadap rumusan negara hukum. Realitas ini memiliki relevansi dengan teori Dawson ${ }^{33}$ tentang konstitusi, lepas dari tertulis atau tidak. Konstitusi dalam pandangan Dawson merupakan kristalisasi dari kepentingan politik, ekonomi, dan budaya pada zamannya. Dinamika dan tekanan nasional merupakan faktor-faktor yang merangsang perubahan konsepsi konstitusi.
Di samping teori tersebut, sikap MPR, karena berkorelasi dengan kepentingan politik, maka memiliki relevansi dengan teori Friedman ${ }^{34}$ tentang sistem hukum. Khususnya tentang budaya hukum. Budaya hukum, sebagai bagian dari sistem hukum berfariasi dalam satu komunitas masyarakat. Fariasi budaya hukum tersebut ditentukan oleh kepentingan, orientasi nilai dan tujuan-tujuan masyarakat atau kelompok tersebut.

Individualisme barat, yang tertransformasi ke dalam segmen kehidupan masyarakat, harus dimengerti dalam konteks sosial historis kemunculannya. Individualisme yang ditransformasi ke dalam hubungan antara rakyat dengan pemerintah, dimaksudkan untuk mengeliminasi praktik kekuasaan tersembunyi. Kekuasaan silent power di masa lalu, telah melahirkan diskriminasi, bukan saja pelayanan terhadap publik, melainkan menimbulkan diskriminasi. Auerbach ${ }^{35}$ melihat esensi dari transformasi tersebut adalah menghindari terbangunnya hubungan yang bersifat paternalistik. Legalisasi sosiologis atas konsep tersebut merupakan kontras terhadap otokratisme tua. Dari sudut ini terlihat juga, sedang terbangun sebuah nilai baru; individualisme.

Kendati demikian tidak mudah untuk ditransformasi secara sistematis ke dalam rumusan-rumusan hukum menjadi suatu konsep hukum. Ambiguitas akan semakin nyata manakala diperdebatkan secara formal HIm. 137.

${ }^{33}$ Robert Mc Gregor Dawson. 1957. The Goverment of Canada. Toronto: University of Toronto Press.

${ }^{34}$ L. M. Friedman. 1984. American Legal System. New York: W. W. Northon. HIm. 5-10.

${ }^{35}$ Jerold S. Aurbach. 1983. Justice Whitouth Law. New York: Oxford University Press. HIm. 29. 
dan politis dalam sebuah institusi politik atau hukum yang otoritatif. Dalam konteks Indonesia, MPR misalnya, mengorientasikan, demikian juga memberikan suatu terminologi menjadi nilai bersama yang bermakna legalistik secara sistematik memerlukan perhatian lebih. Unintended Consecuences, misalnya merupakan suatu konsep yang mengisyaratkan, betapa selalu terjadi sesuatu yang terbayangkan ketika sebuah konsep hukum dirumuskan. Secara kalkulatif, kemunculan unintended consecuences berkorelasi dengan tiga hal: Pertama, konsep dan terminologi baru tersebut memiliki keselarasan eksistensial dengan nilai yang sesungguhnya; Kedua, bagaimana kemungkinan penerapannya; Ketiga, keselarasan public policy dan ketekunan dalam melaksanakannya. ${ }^{36}$

Kendati berbeda setting dan objek yang dibahas, konflik nilai, tentu karena perbedaan dan kompetisi antara penganut dan pendukung, Rickard Quiney ${ }^{37}$ melihat secara statistical masyarakat tersegmentasi ke dalam berbagai segmen. Setiap segmen memiliki nilainya sendiri, dan mengorganisasikan kelompoknya untuk mempromosikan nilai-nilai tersebut. Bagaimana relasinya dengan pemerintah. Bagi Quiney, pemerintah sebagai satu segmen politik memiliki kekuataan yang dapat memaksakan nilainya untuk dianut sebagai social conduct bagi masyarakat. Hukum, bagi Quiney diformulasikan sesuai dengan kepentingannya. Demokrasi yang dipahami dalam terminologi barat sebagai pemerintahan dari rakyat untuk rakyat, harus dipahami dalam konteks nilai dianut oleh masyarakat barat pada zamannya. Kebangkitan demokrasi sebagai sebuah nilai, didorong oleh penghancuran eksistensial manusia secara utuh. Penghancuran ini terjadi dan dilakukan dalam kekuasaan yang bersifat monarchy atau otokratis. ${ }^{38}$ Konstruksi independenci pengadilan, sebuah elemen dasar dari gagasan negara hukum, misalnya, merupakan reaksi atas instrumentasi pengadilan oleh kekuasaan absolut. Bagaimana mengalihkan konteks sosial uraian-uraian tersebut ke dalam konteks reformulasi gagasan negara hukum di Indonesia? Demikian juga bagaimana menentukan signifikansinya . dalam. penggunaan teori.

MPR, sebagai sebuah. institusi konstitusional, karena wewenang yang disandangnya, memiliki kekuasaan untuk mereformulasikan gagasan negara hukum. Persoalannya adalah, institusi tersebut tidak berbicara sendiri melainkan melalui ketua dan anggotanya. Disebabkan oleh keragaman nilai, keyakinan dan kepentingan politik yang disandangnya pula, maka setidak-tidaknya menimbulkan beberapa persoalan. Pertama, Reformulasi gagasan negara hukum, bagaimanapun akan melintasi perdebatan, pertarungan dan pada tingkat yang paling

${ }^{36}$ Roman Tomasaic. 1980. Legislation and Society in Australia. Nort Sidney Australia: George Allen \& Unwin. Him. 35.

${ }^{37}$ Richard Quiney. 1970. The Social Reality of Crime. New York: Litle Brown. HIm. 39.

${ }^{38}$ James Robert. "Recapturing Democracy in a Modern Age." Dalam Eugene Coutran dan Abdel Oemar Sherif. 1999. Democracy, Rule of law and Islam. London: Cimel. HIm. 74. 
mungkin akan dilakukan kompromi. Kedua Perdebatan, pertarungan dan kompromi tersebut akan berlangsung dalam tahapan pembahasan gagasan negara hukum. Ketiga, kekuatan dan keseimbangan politik akan sangat menentukan tingkat, sifat, dan corak perdebatan.

Gagasan negara hukum yang demokratis merupakan refleksi dan reaksi atas kekuasaan sewenang-wenang, sesuai kadar dan persepsi yang terkristal dalam masyarakat dan diapresiasi oleh MPR, dapat dijadikan suatu asumsi yang aplicable. Di sisi lain hukum, diasumsikan sebagai refleksi atas relasi, kepentingan dan nilai yang berkembang dalam masyarakat dan diberi bentuk hukum oleh institusi negara yang otoritatif. Gagasan yang diformalkan dalam konstitusi atau produk konstitusional lainnya, merupakan refleksi atas nilai sosial, budaya ekonomi dan politik masyarakat. Tentu merupakan puncakpuncak dan kristalisasi dari perdebatan, pertarungan serta kompromi para perumus. Berdasarkan uraian tersebut, maka teori yang layak digunakan adalah teori sistem hukum Friedman. Teori ini ditopang oleh teori Lev. Menurut Lev ${ }^{39}$ realisasi gagasan negara hukum membutuhkan bekerjanya faktor hukum dan non hukum. Demikian juga teori Dawson ${ }^{40}$ tentang perubahan konstitusi sebagai pengadaptasian gagasan-gagasan baru, nasional maupun internasional.

\section{Simpulan}

Sungguhpun teori hukum alam, begitu juga positivisme memiliki signifikansi dalam menjelaskan fenomena negara hukum, secara faktual teori-teori tersebut memiliki beberapa kelemahan. Kelemahannya terletak pada pembenaran terhadap postur negara yang bercorak otoritarian. Sehingga tidak terlampau tepat untuk digunakan menjelaskan fenomena negara hukum yang demokratis. Apalagi menjelaskan proses pengadaptasian aspirasi demokratik masyarakat tentang postur kehidupan bernegara.

Konvigurasi nilai, kepentingan, harapan dan persepsi komunitas politik di MPR, secara teoritik menandai signifikansi teori sistem yang dikembangkan Friedman. Tiga unsur dasar dalam teori tersebut; substansi, struktur dan budaya hukum, lengkap dengan constrain dan efek-efeknya, secara fungsional sangat komprehensif untuk mengungkap fenomena perumusan gagasan negara hukum yang dilakukan oleh MPR. Jika hendak dikelompokan berdasarkan aliran-aliran pemikiran dalam filsafat maupun ilmu hukum, maka teori ini berada dalam kawasan sosiologi hukum (Sociological jurisprudence).

Hukum tatanegara mutakhir akan menjadi lebih kaya, baik dalam konteks analisis maupun penyajian informasi, jika dijelaskan berdasarkan paradigma sosiologis. Tujuan itu akan tercapai bila diperhatikan dua hal. Pertama, isu-isu yang hendak dijelaskan harus diperiksa dan disajikan secara kritis. Kedua,

\footnotetext{
${ }^{39}$ L. M. Friedman. Op. Cit. HIm. 219-220.

${ }^{40}$ Dawson. Op.Cit. Him. 137.
} 
harus dihindari gaya penyajian model Jerman, terutama tradisi Hegelian. Tradisi yang menganggap apa yang nyata adalah rasional, dan yang rasional adalah yang nyata.

\section{Daftar Pustaka}

Adji, Oemar Seno. 1980. Peradilan Bebas Negara Hukum. Jakarta: Erlangga.

Andrian, Charles. "Political Live and Social Change." Di-indonesiakan oleh Lukman Hakim. 1992. Kehidupan Politik dan Perubahan Sosial. Jakarta: Tiara Wacana.

Anwar, Dewi Fortuna. "Format Politik Orde Baru dan Agenda Pengembangan Demokrasi Politik "Dalam Syarofin(ed). Demitologisasi Politik Indonesia Mengusung Elitisme Dalam Orde Baru. Jakarta: CIDES.

Apter, David. 1996. Pengantar Analisa Politik. Jakarta: LP3ES.

Arief, Sritua. 1997. Pembangunanisme dan Ekonomi Indonesia. Pemberdayaan Rakyat Dalam Arus Globalisasi. Jakarta: Zaman.

Auerbach Jerold S. 1983. Justice Whitouth Law. New York. London, Melbrone: Oxford University Press.

Budiman, Arief. 1991. Negara dan Pembangunan Studi Tentang Indonesia dan Korea Selatan. Jakarta: Yayasan Padi dan Kapas.

Chan, Harry. 1994. Modem Jurisprudence. Singapore: Turbo.
Davidson, Scot. "Human Rights." Dilndonesiakan oleh H. Hadyana Pujaatmaka. 1994. Hak Asasi Manusia. Jakarta: Pustaka Utama Grafiti.

Dawson, Robert Mac. 1957. The Goverment of Canada. Toronto: University Press.

Friedman, W. Legal Theory. Diindonesiakan oleh Arifin. 1991. Filsafat Hukum. Telaah Kritis Atas Teori Hukum (susunan III). Jakarta: Rajawali.

Friedman, Lawrence M. 1975. Legal System, A Social Sciences Perspective Theory. New York: Russel Sage Foundation.'

1984. American Legal System. New York-London: W.W. Northon.

Gobert, James. "Recupturing Democracy In A Modern Age." In Eugene Cotran And Adel Omar Sherif. 1999. Democracy, Rule of Law and Islam. London: CIMEL.

Harman, Beny K. 1997. Konvigurasi Politik dan Kekuasaan Kehakiman Di Indonesia. Jakarta: ELSAM.

Hartono, Sunaryati. 1966. Apakah The Rule of Law. Bandung: Alumni.

Jhones, Howard Palfrey. 1980. Indonesia: The Posible Dream. Jakarta: Gunung Agung.

J.J. Schemid. "Het Denken Over Staat En Recht In de Negertiende." Diterjemahkan Oleh Buntaran. 1967. Negara dan Hukum. Jakarta: Erlangga.

Kusuma, Mulyana. W. 1988. Hukum, Politik dan Perubahan Sosial. Jakarta: YLBHI. 
Lev, Daniel S. "JudicialAuthority and the Strugle for an Indonesian Rechstaat.". Law and Society Review. (1978).

-—- 1991. Hukum dan Politik Di Indonesia. Kesinambungan dan Perubahan. Jakarta: LP3ES.

Lloyd's, and M.D.A. Freeman. 1985. Introduction to Jurisprudence. London: Steven \& Son.

Mahendra, Yusril Ihza. 1996. Dinamika Tatanegara Indonesia. Kompilasi Aktual Masalah Konstitusi, Dewan Perwakilan dan Sistem Perwakilan Rakyat. Jakarta: Gema Insani Press.

Nasution, Abdulharis. 1966. KetetapanKetetapan MPRS. Jakarta: Tanpa Penerbit.
Peters, G. A. A. \& Koesriani Siswosoebroto. 1990. "Hukum dan Perkembangan Sosial." Buku Teks Sosiologi Hukum Buku III. Jakarta: Sinar Harapan.

Posner, Richard. 1996. Law and Legal Theory in England and America. Oxford: Clarendom.

Presser, Steven B. \& Jamil S. Jainaldin. 1980. Law and American History. New York: West Publishing.

Queney, Richard. 1970. The Social Realitiy of Crime. New York: Litle Brown.

Raz, Jhoseph. 1983. The Authority of Law Essays on Law and Morality. Oxford: Clarendom.

Suny, Ismail. 1986. Pergeseran Kekuasaan Eksekutif. Jakarta: Aksara Baru.

Tomasaic, Roman. 1980. Lagislation and Society in Australia. Nort Sidney Australia: George Allen \& Undwin Australia. Ltd.

\section{米米将}

TDosen Fak. Hukum Universitas Khairun Ternate. 